\title{
Supplementation of dairy cows with propylene glycol during the periparturient period: effects on body condition score, milk yield, first estrus post-partum, $\beta$-hydroxybutyrate, non-esterified fatty acids and glucose concentrations
}

\author{
Suplementação de vacas em lactação com propilenoglicol durante o período peri-parto: efeitos sobre o \\ escore de condição corporal, produção de leite, primeiro estro pós-parto e concentrações de $\beta$ - \\ hidroxibutirato, ácidos graxos não-esterificados e glicose
}

\section{Luís Fernando Laranja da Fonseca ${ }^{1}$ Paulo Henrique Mazza Rodrigues ${ }^{1}{\text { Marcos Veiga dos } \text { Santos }^{2}}^{2}$ André Pinto Lima ${ }^{3}$ Carlos de Sousa Lucci ${ }^{4}$}

\section{RESUMO}

O objetivo do presente estudo foi o de analisar os efeitos da suplementação de propilenoglicol (PPG) para vacas no período peri-parto sobre a produção de leite, mudanças no escore de condição corporal (ECC), número de dias para o primeiro cio pós-parto, concentrações plasmáticas de bhidroxibutirato (BHBA), ácidos graxos não-esterificados (AGNE) e glicose. Vinte e três vacas da raça Holandesa foram alocadas em dois tratamentos: a) $300 \mathrm{~mL}$ de PPG (grupo tratamento, 11 vacas), b) $300 \mathrm{~mL}$ de água (grupo controle, 12 vacas), administrados através de beberagem no período peri-parto. Amostras de plasma foram coletadas durante os dias -10, -5, 0, $3,7,14,21,28,35,42$ e 49 em relação à data do parto para análises de BHBA, AGNE e glicose. O ECC foi avaliado nos dias $-10,0,15,30,45$ e 60 em relação à data do parto. Não houve efeito do tratamento ou tempo sobre a produção de leite, embora a interação tempo*tratamento foi significativa, sendo que entre a $4^{\underline{a}}$ e $5^{\underline{a}}$ semana de lactação, a produção de leite foi significativamente maior para o grupo tratamento. Não houve efeito do tratamento sobre o ECC do parto até 60 dias de lactação. $O$ número de dias para o primeiro cio pós-parto para o grupo PPG e controle foi em média 40,2 e 45,2, respectivamente. Não houve efeito do tratamento da interação tempo *tratamento sobre as concentrações plasmáticas de BHBA, AGNE e glicose, mas houve efeito do tempo sobre a concentração de glicose e AGNE. A suplementação de PPG apresenta efeito pouco importante na redução dos efeitos metabólicos negativos que ocorrem durante o início da lactação de vacas leiteiras.
Palavras-chave: vaca leiteira, propilenoglicol, produção leiteira, escore de condição corporal, desempenho reprodutivo.

\section{ABSTRACT}

The objective of this study was to analyse the effects of propylene glycol (PPG) supplementation to periparturient cows on: milk yield, changes in body condition score (BCS), days to first oestrus after calving, and on the b-hydroxybutyrate (BHBA), non-esterefied fatty acids (NEFA) and glucose concentrations. Twenty-three Holstein cows were distributed into two treatments: a) $300 \mathrm{~mL}$ of PPG (group treatment, 11 cows), b) $300 \mathrm{~mL}$ of water (group control, 12 cows), administered via drench in periparturient period. BCS was evaluated on days $-10,0,15,30,45$ and 60 relative to calving date. There was no effect of treatment or time on milk yield, although the interaction of time*treatment was significant and during the 4th and 5th week of lactation, milk yield was significant higher in treatment group. Days to first oestrus of PPG and control group were on average 40.2 and 45.2 respectively $(P>0.05)$. There was no effect of treatment on body condition score (BCS) from calving to sixty days post partum. There was no effect of treatment or interaction of time*treatment on plasma parameters (BHBA, NEFA and glucose) but there was an effect of time on glucose and NEFA. However, based on an analysis of covariance, using BCS as the covariate, an effect of treatment on plasma concentrations of BHBA was observed. In conclusion, supplementation of propyleneglycol has a minor effect to alleviate the negative metabolic effects that normally occur at early lactation in dairy cows.

${ }^{1}$ Médico Veterinário e Professor Doutor, Departamento de Nutrição e Produção Animal, Faculdade de Medicina Veterinária e Zootecnia (FMVZ), Universidade de São Paulo (USP), Campus de Pirassununga.

${ }^{2}$ Médico Veterinário, Professor, Doutor, Departamento de Nutrição e Produção Animal, FMVZ, USP, CP 23, R. Duque de Caxias Norte, 225, 13630.090, Pirassununga, São Paulo, Brazil. Phone +55 193565 4240, FAX: +55 195616215 . E-mail: mveiga@usp.br Autor para correspondência.

${ }^{3}$ Médico Veterinário, autônomo.

${ }^{4}$ Médico Veterinário e Professor Titular, Departamento de Nutrição e Produção Animal, FMVZ, USP, Campus de Pirassununga. 
Key words: dairy cow; propylene glycol, milk yield, body condition score, reproductive performance.

\section{INTRODUCTION}

During peripartum period, high producing dairy cows have decreased dry matter intake (DMI) (VAZQUEZ-AÑON et al., 1994), which leads to a high mobilisation of body fat reserves in order to fulfill the increased demand of energy for milk synthesis. The negative energy balance (NEB) that results from the increased demand for nutrients for milk synthesis during the postpartum period is considered one of the main factors that may negatively affect milk yield and reproduction performance in dairy cows (BUTLER \& SMITH, 1989).

High producing dairy cows have an elevated demand for glucose by the mammary gland in order to produce lactose. Regarding the circulating glucose, there is conflicting data in the literature. BREMMER et al. (2000) reported that glucose concentration is decreased in response to energy restriction in the diet, while CANFIELD \& BUTLER (1991) concluded that there is little influence of the energetic status of the animal on the blood glucose concentration. The reduced availability of glucogenic compounds during the negative energy balance period may also lead to fatty liver syndrome (GRUMMER, 1993), which is associated with decreased milk yield and reproductive performance.

Since dairy cows have limited capacity of DM intake during periparturient period (LUCY et al., 1992; VAZQUEZ-AÑON et al., 1994) some research has focused on strategies for increasing the energy density of diets mainly through feeding ionophors (TURNER et al., 1980), niacin (JASTER \& WARD, 1990), the use of by-pass fat (SON et al., 1996), and the use of glugogenic compounds as calcium propionate and propylene glycol (PPG) (STUDER et al., 1993).

The use of PPG during periparturient period via oral drench or mixed with the diet has been suggested as one alternative to alleviate the negative energy balance (STUDER et al., 1993) and, therefore improve reproductive performance (FORMIGONI et al., 1996; MYIOSHI et al, 2001) and to reduce the incidence of acetonemia (GRUMMER, 1993). After its ingestion, PPG escapes the ruminal fermentation and is metabolized by the liver into glucose through the lactaldehyde pathway and subsequent oxidation to lactate (MILLER \& BAZZANO, 1965). The supplementation of PPG during the periparturient period has been effective in reducing plasma $B$ hydroxybutyrate (BHBA), nonesterified fatty acids (NEFA), urea concentration while increasing plasma glucose, insulin, cholesterol and IGF-1 (GRUMMER et al., 1994; FORMIGONI et al., 1996).

The objective of this study was to evaluate the effect of PPG administration to periparturient dairy cows on milk yield, changes in body condition score (BCS), number of days to first estrus after calving and on BHBA, NEFA and glucose plasma concentrations.

\section{MATERIAL AND METHODS}

\section{Experimental design}

Twenty-three Holstein cows from a commercial herd located in São Paulo State, Brazil, were used in this experiment. The animals were distributed into two treatment groups: a) propylene glycol treated group (11 animals), b) control group (12 animals). PPG (treated group) and water (control group) were supplied via drench in a volume of 300 $\mathrm{ml}$ on days $-10,-5,-4,-3,-2,-1,0,2,4,6,8,10,12$, 14 and 16 relative to calving date.

All animals used in this study were housed in a free-stall barn with free access to a maternity pen for 21 days prior to parturition and fed an ad libitum total mixed ration twice a day, according to table 1 . After parturition all animals were milked to provide colostrum for the calves and housed in a free stall for the first 90 days of lactation and being fed an ad libitum total mixed ration twice a day, according to table 1 .

Blood samples were collected on days -10 , $-5,0,3,7,14,21,28,35,42$ and 49 in relation to calving date from the coccygeal vein using heparinized Vacutainer ${ }^{\circledR}$ tubes (Becton Dickinson, New Jersey, USA) 90 minutes after the administration of PPG or water, according to procedures described by GRUMMER et al. (1994). After collection, blood samples were stored for no more than 5 minutes on ice until centrifugation, at $1,000 \mathrm{G}$, for 25 minutes for plasma separation. Plasma aliquots of $1 \mathrm{ml}$ were stored at $-20^{\circ} \mathrm{C}$ until analysis of BHBA, NEFA and glucose.

\section{Analytical methods}

Glucose concentrations were determined using a Sigma kit number 315-100 (Sigma Diagnostics, St. Louis, MO, USA), based on glucose oxidase method as described by TIETZ (1982). Plasma BHBA concentrations were analysed using the Sigma 310-A UV kit (Sigma Diagnostics, St. Louis, MO, USA), based on an enzymatic method according to WILLIANSOM et al. (1962). Plasma NEFA concentrations were determined using an enzymatic 
Table 1 - Ingredient and nutrient composition of total mixed ration (TMR), based on dry matter (DM).

\begin{tabular}{lcc}
\hline & \multicolumn{2}{c}{$\%$ of DM } \\
\cline { 2 - 3 } Ingredients & Pre-partum & Post-partum \\
\hline Corn silage & 43.5 & 34.3 \\
Whole Cottonseed & 4.5 & 8.9 \\
Coast cross hay & 17.0 & 4.2 \\
Ground corn & 8.7 & 20.5 \\
Soybean meal & 15.6 & 18.8 \\
Citrus pulp & 4.3 & 8.6 \\
Mineral Premix & \\
Anionic Premix & 4.7 & 4.7 \\
Nutrient composition & 1.7 & - \\
Dry matter (\%) & & \\
Crude Protein (\%) & 42.20 & 47.60 \\
Undegradable protein (\%) & 16.14 & 18.16 \\
Net energy for lactation (Mcal/kg) & 29.91 & 32.77 \\
Total digestible nutrients (\% DM) & 1.49 & 1.69 \\
Acid detergent fiber (\%) & 66.01 & 73.86 \\
Neutral detergent fiber (\%) & 25.78 & 20.29 \\
Ether Extract (\%) & 43.84 & 32.86 \\
Ca (\%) & 3.30 & 4.28 \\
P (\%) & 1.39 & 0.90 \\
\hline & 0.36 & 0.53 \\
\hline
\end{tabular}

${ }^{1}$ Composition per kg of mineral premix: $651.2 \mathrm{~g}$ limestone; $323.6 \mathrm{~g}$ dicalcium phosphate; $11.68 \mathrm{~g}$ elemental sulfur; $4.67 \mathrm{~g}$ copper sulfate; $5.02 \mathrm{~g}$ zinc oxide; $3.50 \mathrm{~g}$ manganese sulfate; $0.175 \mathrm{~g}$ cobalt sulfate; $0.140 \mathrm{~g}$ calcium iodine and $0.0234 \mathrm{~g}$ sodium selenite.

colorimetric kit (Wako Nefa C, Wako Pure Chemical Industries, Ltd., Osaka, Japan).

\section{Body condition score evaluation and reproductive parameters and milk yield}

During the experimental period, BCS was evaluated by the same person on days $-10,0,15,30$, 45 and 60 relative to day of parturition. Evaluation was performed as described by WEAVER (1986) using a five-point scale (1: thin; 5: obese).

After parturition, the interval from calving to first estrus was evaluated by a radiotelemetric device system (HeatWatch ${ }^{\circledR}$, Denver, CO, EUA) according to WALKER et al. (1996). Milk yield was measured weekly starting on the second week up to the twelfth week of lactation.

\section{Statistical analysis}

Plasma NEFA, BHBA and glucose, milk yield, BCS and interval from calving to first estrus were submitted to analysis of variance with repeated measures on time, according to different sampling days. Data were analysed using the REPEATED procedure of GLM of SAS (SAS, 1985). Significance was declared at $P<0.05$.

\section{RESULTS AND DISCUSSION}

\section{Body condition score (BCS)}

Results of BCS in a five-point scale are shown in the table 2. Average BCS for PPG treated group (3.27) was higher than for control group (2.97). A significant quadratic effect of time on $\operatorname{BCS}(P=0.02)$ was observed, however, there was no interaction between time and treatment $(\mathrm{P}=0.58)$. Results for BCS observed in this study are in agreement with those obtained by SMITH et al. (1997) indicating a mobilisation of body fat reserves after parturition for the energy requirements for maintenance and lactation. In this study, the variation in BCS from parturition to 60 days in milk (DIM) was 1.02 and 1.17 for treatment (PPG) and control group, respectively, which is higher when compared to results obtained by FORMIGONI et al. (1996) (0.34 versus 0.50 for treated and control group, respectively). This higher mobilisation of fat observed in this study was probably due to the higher initial average BCS of the animals (3.60) when compared to that reported by FORMIGONI et al. (1996) of 3.20. According to SMITH et al. (1997), animals that have higher BCS are more prone to have a lower DMI and higher weight loss after parturition. Therefore, PPG supplementation had no effect on the BCS variation from parturition to 60 DIM indicating that it was not able to alleviate the reduction in BCS in early lactation, which is in agreement with results reported by FORMIGONI et al. (1996).

\section{First oestrus postpartum}

Supplementation of PPG in the present study had no effect on time interval to first oestrus postpartum $(P=0.31)$, even though animals from the treatment group had an earlier post partum return to oestrus when compared to the control group (40.1 versus 45.1 days, respectively). Results obtained by this study are not in agreement with those reported by FORMIGONI et al. (1996). These authors compared the effect of PPG supplementation during the 10 days before parturition and on days 3, 6, 9 and 12 after parturition, reporting a significant earlier post partum return to oestrus in PPG treated group (20 cows) than in untreated cows (19 cows) measured by progesterone levels. The percentage of acyclic cows during the first 96 days post partum was 30 and $58 \%$ for the treated and control group, respectively $(P<0.001)$. However, the reproductive performance of both treated and control groups was not satisfactory.

Ciência Rural, v.34, n.3, mai-jun, 2004. 
Table 2 - Effect of propylene glycol (PPG) supplementation on body condition score (BCS) from 10 days prior to parturition to 60 days in milk.

\begin{tabular}{|c|c|c|c|c|c|}
\hline \multirow{2}{*}{ BCS (days) } & \multirow{2}{*}{ Control } & \multicolumn{2}{|c|}{ Treatments } & \multirow{2}{*}{$\mathrm{CV}^{3}$} & \multirow{2}{*}{$P$} \\
\hline & & PPG & Average & & \\
\hline BCS $-10^{1}$ & 3.75 & 4.05 & 3.89 & 12.59 & NS \\
\hline BCS 0 & 3.46 & 3.73 & 3.59 & 11.87 & NS \\
\hline BCS 15 & 3.04 & 3.23 & 3.13 & 13.71 & NS \\
\hline BCS 30 & 2.75 & 3.00 & 2.87 & 12.00 & 0.08 \\
\hline BCS 45 & 2.54 & 2.85 & 2.68 & 16.74 & 0.02 \\
\hline BCS 60 & 2.29 & 2.75 & 2.50 & 20.88 & 0.02 \\
\hline Average & 2.97 & 3.27 & 3.11 & 20.47 & 0.01 \\
\hline Dif $60 / 0^{2}$ & -1.17 & -1.02 & -1.09 & 39.09 & NS \\
\hline
\end{tabular}

${ }^{1} \mathrm{BCS}-10=\mathrm{BCS}$ at 10 days prior to parturition;

${ }^{2}$ Dif $60 / 0=$ BCS variation from parturition to 60 DIM.

${ }^{3} \mathrm{CV}=$ coefficient of variation

Considering that reproductive performance is one of the most important factors that may affect profitability of dairy farms (STEVENSON \& CALL, 1988), there is antagonism between milk yield and reproductive performance (CANFIELD \& BUTLER, 1991). The deficiency of energy in the post partum period seems to be the main factor that may negatively affect reproductive performance in dairy cows (LUCY et al., 1992). Several nutritional strategies have been studied aiming to diminish the impact of negative energy balance during the post partum period, such as supplementation with fat (SON et al., 1996), niacin (JASTER \& WARD, 1990), ionophors (HAYES et al., 1996) and PPG (FORMIGONI et al., 1996). However, the results of those studies have not indicated which metabolic compounds are positively associated with the resumption of oestrus cycles and first oestrus post partum (HANSEN, 1991). In herds with high incidence of post partum metabolic disorder, such as fatty liver and clinical and subclinical ketosis, the supplementation of PPG may improve the reproductive performance (MIETTINEN, 1991).

The effect of PPG supplementation on reproductive performance in periparturient dairy cows seems to be more related to some metabolic and hormonal profile such as insulin, IGF-1, glucose and NEFA (STUDER et al., 1993; FORMIGONI et al., 1996), than to its direct effect on reducing the negative energy balance (FISHER et al., 1973).

\section{Milk yield}

Milk production was recorded weekly from the second week of lactation up to 12 weeks of lactation. PPG supplementation had no effect on milk yield during the overall experimental period $(\mathrm{P}=0.29)$ as reported by MYOSHI et al. (2001), however a significant interaction was detected between time and treatment $(\mathrm{P}=0.03)$, as shown in table 3 . Results observed in the present study are in agreement with those reported by STUDER et al. (1993) and FORMIGONI et al. (1996) that reported a non significant effect of PPG supplementation on milk yield.

In the present experiment, average milk yield from the $2^{\text {nd }}$ to $12^{\text {th }}$ week post partum was 24.5 and $27.03 \mathrm{~kg} / \mathrm{d}$ for control and treated groups, respectively. A higher milk yield $(P<0.05)$ was observed for PPG treated group during the 4th week of lactation, which is in accordance with results

Table 3 - Effect of propylene glycol (PPG) supplementation on milk yield $(\mathrm{kg} / \mathrm{d})$.

\begin{tabular}{lccccc}
\hline \multirow{2}{*}{$\begin{array}{l}\text { Post partum } \\
\text { week }\end{array}$} & \multicolumn{2}{c}{ Treatments } & & \\
\cline { 2 - 4 } & Control & PPG & & & \\
\hline 2 & 22.38 & 22.90 & 22.64 & 20.31 & NS \\
3 & 25.16 & 25.53 & 25.35 & 17.83 & NS \\
4 & 22.35 & 28.11 & 25.37 & 23.06 & 0.02 \\
5 & 23.54 & 28.10 & 25.93 & 20.79 & 0.05 \\
6 & 23.55 & 28.56 & 26.06 & 23.86 & 0.07 \\
7 & 23.98 & 29.17 & 26.45 & 23.65 & 0.05 \\
8 & 24.58 & 28.35 & 26.38 & 20.97 & NS \\
9 & 26.01 & 27.48 & 26.71 & 21.39 & NS \\
10 & 26.32 & 26.21 & 26.27 & 17.37 & NS \\
11 & 25.96 & 26.89 & 26.40 & 16.72 & NS \\
12 & 25.34 & 25.41 & 25.37 & 19.06 & NS \\
\hline Average & 24.53 & 27.03 & 25.76 & 20.55 & NS \\
\hline
\end{tabular}

${ }^{1} \mathrm{CV}=$ coefficient of variation

NS: non significant. 
reported by FISHER et al. (1973), but milk production was not significantly higher during the whole period as obseved by STUDER et al. (1993) e FORMIGONI et al. (1996).

A decrease in milk yield was observed in the $4^{\text {th }}$ week of lactation for the control group. According to ANDERSON (1988), a decrease in milk production can be observed during the $4^{\text {th }}$ and $8^{\text {th }}$ week of lactation of cows with higher milk acetone concentration. This author reported that the milk yield depression is more severe in cows presenting high milk acetone levels. In the present study, the number of cows that had acetonemia measured by plasma BHBA concentration was higher for the control group (9.1 and $33.5 \%$; respectively), which could explain the milk yield depression observed.

\section{Plasma glucose concentration}

Results from plasma glucose concentration are shown in table 4. The supplementation of PPG had no effect on the concentration of plasma glucose concentration $(P=0.88)$ and no interaction between treatment and time was identified $(P=0.85)$. A significant effect of time on plasma glucose concentration $(P<0.001)$ was observed which is in agreement with results reported by STUDER et al. (1993), FORMIGONI et al. (1996), and MIYOSHI, et al. (2001). According to STUDER et al. (1993) and VAZQUEZ-AÑON et al. (1994) there is a peak in the blood glucose concentration during parturition followed by its decrease after parturition. This increase in the blood glucose concentration is due to the neoglucogenesis and the glucogenolysis stimulated by glucocorticoids and cathecolamins during parturition.

VAZQUEZ-AÑON et al. (1994) reported an increase in blood glucose concentration after the second week of lactation that can be explained by the increase in the dry matter intake and consequently an improvement in the energy status. However, the results obtained in the present study indicate that glucose concentration was kept low up to the $7^{\text {th }}$ week of lactation, which is in agreement with results reported by STUDER et al. (1993).

\section{Plasma NEFA concentration}

Results from plasma NEFA concentration are shown in table 4. The supplementation of PPG had no effect on the concentration of plasma NEFA concentration $(P=0.90)$ and no interaction between treatment and time was identified $(P=0.67)$. A significant effect of time on plasma NEFA concentration $(P<0.001)$ was observed which is in agreement with results reported by FORMIGONI et al. (1996) and MIYOSHI, et al. (2001).

Plasma NEFA concentration was lower in the PPG treated group at 3 days prepartum $(P=0.001)$. These results are in agreement with the results reported by FORMIGONI et al. (1996). The increase in plasma NEFA concentration before parturition in the control group is caused by and augmented energetic demand by fetal growth and endocrine changes. STUDER et al. (1993) observed a significant $(P<0.01)$ increase in

Table 4 - Effect of propylene glycol (PPG) supplementation plasma concentration of glucose, non-esterefied fatty acids (NEFA) and $\beta$ hydroxybutyrate (BHBA)

\begin{tabular}{|c|c|c|c|c|c|c|c|c|c|c|c|c|}
\hline \multirow{2}{*}{ Day $^{2}$} & \multicolumn{4}{|c|}{ Glucose (mg/dL) } & \multicolumn{4}{|c|}{$\operatorname{NEFA}(\mu \mathrm{eq} / \mathrm{L})$} & \multicolumn{4}{|c|}{ BHBA (mg/dL) } \\
\hline & Control & PPG & $\mathrm{CV}^{1}$ & $P$ & Control & PPG & $\mathrm{CV}^{1}$ & $P$ & Control & PPG & $\mathrm{CV}^{1}$ & $P$ \\
\hline-10.5 & 66.50 & 68.71 & 8.41 & NS & 247.10 & 200.14 & 37.99 & NS & 4.78 & 3.34 & 42.90 & 0.08 \\
\hline-3.5 & 68.86 & 67.00 & 11.08 & NS & 330.00 & 217.17 & 30.62 & $<0.001$ & 5.30 & 3.48 & 37.70 & 0.04 \\
\hline 0 & 87.25 & 87.64 & 28.86 & NS & 764.25 & 626.45 & 55.28 & NS & 6.64 & 3.90 & 53.25 & 0.02 \\
\hline 3 & 68.42 & 73.73 & 25.86 & NS & 696.00 & 687.73 & 57.05 & NS & 7.32 & 5.01 & 76.76 & NS \\
\hline 7 & 64.83 & 60.27 & 11.74 & NS & 474.83 & 509.64 & 40.17 & NS & 6.07 & 4.73 & 64.14 & NS \\
\hline 14 & 65.92 & 63.64 & 14.43 & NS & 407.08 & 341.64 & 54.20 & NS & 5.90 & 3.49 & 70.95 & 0.08 \\
\hline 21 & 58.50 & 59.91 & 9.99 & NS & 389.08 & 321.18 & 65.97 & NS & 8.82 & 5.55 & 91.18 & NS \\
\hline 28 & 61.25 & 62.82 & 11.94 & NS & 356.67 & 323.82 & 57.17 & NS & 7.65 & 5.07 & 82.77 & NS \\
\hline 35 & 58.25 & 60.64 & 14.11 & NS & 360.00 & 294.55 & 70.66 & NS & 9.38 & 6.42 & 112.58 & NS \\
\hline 42 & 60.75 & 59.91 & 9.68 & NS & 237.42 & 304.73 & 60.05 & NS & 5.52 & 5.20 & 38.78 & NS \\
\hline 49 & 60.45 & 63.18 & 11.16 & NS & 222.91 & 253.91 & 46.00 & NS & 5.49 & 5.45 & 50.94 & NS \\
\hline Mean & 65.44 & 66.00 & 21.31 & NS & 414.98 & 383.96 & 70.80 & NS & 6.73 & 4.80 & 80.70 & NS \\
\hline
\end{tabular}

${ }^{1} \mathrm{CV}=$ coefficient of variation

${ }^{2}$ Days relative to relative to calving date

NS: non significant.

Ciência Rural, v.34, n.3, mai-jun, 2004. 
plasma NEFA concentration during the 5 days before parturition in the control group when compared to PPG treated animals.

In the present study plasma NEFA concentration decreased after parturition in both groups with a tendency to stabilize after the $3^{\text {rd }}$ week of lactation, which is in agreement with the results reported by FORMIGONI et al. (1996) and STUDER et al. (1993). However, in the present study no significant differences were observed between treatments in plasma NEFA concentration, while STUDER et al. (1993) reported a tendency $(P<0.10)$ and FORMIGONI et al. (1996) observed a significant difference $(P<0.01)$ between the PPG treated and control group of animals.

\section{Plasma BHBA concentration}

Considering the BCS at parturition as a covariable, a significant effect of treatment in plasma BHBA concentration was observed, with PPG treated animals presenting a lower plasma BHBA concentration $(4.80 \mathrm{mg} / \mathrm{dL})$ when compared to control animals $(5.81 \mathrm{mg} / \mathrm{dL})$. These results could indicate that the assignment of treatments was at random and the difference in BCS at parturition has a significant effect on the plasma BHBA concentration, suggesting that if all animals had the same BCS at parturition, the PPG supplementation could have a significant effect in reducing the plasma BHBA concentration. SAUER et al. (1973) observed a decrease in blood BHBA concentration $(P<0.05)$ with the supplementation of $3 \%$ of PPG in the concentrate only in the $4^{\text {th }}$ and $7^{\text {th }}$ weeks of lactation. STUDER et al. (1993) reported an effect of PPG supplementation of 1 1/cow/day during the 15 days before parturition, while FORMIGONI et al. (1996) observed no effect of PPG supplementation on plasma BHBA concentration. No effect of time $(P=0.14)$ on the plasma BHBA concentration was observed in the present study.

\section{CONCLUSION}

Based on the results obtained, it can be concluded that the supplementation of PPG in the periparturient dairy cow has no effect on the time to first oestrus post partum, glucose, BHBA and on plasma NEFA concentrations during the first seven weeks of lactation. PPG administration does not affect milk yield during the $2^{\text {nd }}$ to the $12^{\text {th }}$ week of lactation, but may increase milk yield during the $4^{\text {th }}$ week post partum. Supplementation of PPG has no effect on the BCS change from parturition to 60 days post partum and has a minor effect to alleviate the negative metabolic effects that normally occur during early lactation in dairy cows.

\section{REFERENCES}

ANDERSON, L. Subclinical ketosis in dairy cows. Veterinary Clinics of North America, Philadelphia, v.4, n.2, p.233, 1988.

BREMMER D.R. et al. Etiology of fatty liver in dairy cattle: Effects of nutritional and hormonal status on hepatic microsomal triglyceride transfer protein. Journal of Dairy Science, Savoy, v.83, n.10, p.2239-2251, 2000.

BUTLER, W.R.; SMITH, R.D. Interrelationships between energy balance and pospartum reproductive function in dairy cattle. Journal of Dairy Science, Savoy, v.72, n.3, p.767-783, 1989.

CANFIELD, R.W.; BUTLER, W.R. Energy balance, first ovulation and the effects of naloxone on LH secretion in early postpartum dairy cows. Journal Animal Science, Savoy, v.69, n.2, p.740746, 1991.

FISHER, L.J. et al. Effects of propylene glycol or glycerol supplementation of the diet of dairy cows on feed intake, milk yield and composition, and incidence of ketosis. Candian Journal of Animal Science, Ottawa, v.53, n.2, p.289-296, 1973.

FORMIGONI, A. et al. Effect of propylene glycol supplementation around parturition on milk yield, reproduction performance and some hormonal and metabolic characteristics in dairy cows. Journal of Dairy Research, Ayr, v.63, n.1, p.11-24, 1996.

GRUMMER, R.R. Etiology of lipid-related metabolic disorders in periparturient dairy cows. Journal of Dairy Science, Savoy, v.76, n.12, p.3882-3896, 1993.

GRUMMER, R.R. et al. Effect of propylene glycol dosage during feed restriction on metabolites in blood of prepartum Holstein heifers. Journal of Dairy Science, Savoy, v.77, n.12, p.36183623,1994

HANSEN, P.J. The relationship between energy status and the resumption of estrus cycles in cattle. Revista Brasileira de Reprodução Animal, Belo Horizonte, n.3, p.200-209, 1991.

HAYES, D.P.; PFEIFFER, D.U.; WILLIAMSON, N.B. Effect of intraruminal monensin capsules on reproductive performance and milk production of dairy cows fed pasture. Journal of Dairy Science, Savoy, v.79, n.6, p.1000-1008, 1996.

JASTER, E.H.; WARD, N.E. Supplemental nicotinic acid or nicotinamida for lactating cows. Journal of Dairy Science, Savoy, v.73, n.10, p.2880- 2887, 1990.

LUCY, M.C. et al. Influence of diet composition, dry-matter intake, milk production and energy balance on time of postpartum ovulation and fertility in dairy cows. Animal Production, v.54, n.3, p.323-331, 1992.

MIETTINEN, P.V.A. Correlation between energy balance and fertility in Finnish dairy cows. Acta Veterinaria Scandinavica, Vanløse, v.32, n.2, p. 189-196, 1991.

MILLER, O.N.; BAZZANO, G. Propanediol metabolism and its relation to lactic acid metabolism. Annals of the New 
York Academy of Science, New York, v.119, n.A3, p.957, 1965.

MIYOSHI, S.; PATE, J.L.; PALMQUIST, D.L. Effects of propylene glycol drenching on energy balance, plasma glucose, plasma insulin, ovarian function and conception in dairy cows. Animal Reproduction Science, Amsterdam, v.68, n.2, p.29-43, 2001.

SAS® user's guide: statistics. Version. 5.ed. Cary, NC : SAS Institute, 1985.

SAUER, F.D.; ERFLE J.D.; FISHER, L.J. Propylene-glycol and glycerol as a feed additive for lactating dairy-cows - evaluation of blood metabolite parameters. Canadian Journal of Animal Science, Ottawa, v.53, n.2, p.265-271, 1973.

SMITH, T.R. et al. Metabolic characteristics of induced ketosis in normal and obese dairy cows. Journal of Dairy Science, Savoy, v.80, n.8, p.1569-1581, 1997.

SON, J.; GRANT, R.J.; LARSON, L.L. Effects of tallow and escape protein on lactational and reproductive performance of dairy cows. Journal of Dairy Science, Savoy, v.79, n.5, p.822$830,1996$.

STEVENSON, J.S.; CALL, E.P. Reproductive disorders in the periparturient dairy cows. Journal of Dairy Science, Savoy, v.71, n.9, p.2572-2583, 1988.
STUDER, V.A. et al. Effect of prepartum propylene glycol administration on periparturient fatty liver in dairy cows. Journal of Dairy Science, Savoy, v.76, n.10, p.2931-2939, 1993.

TIETZ, N.W. Fundamental of clinical chemistry. 2.ed. Philadelphia : Saunders, 1982. 240p.

TURNER, H.A. et al. Effect of various levels of monensin on efficiency and production of beef cows. Journal Animal Science, Savoy, v.50, n.3, p.385-390, 1980

VAZQUEZ-AÑON, M. et al. Peripartum liver triglyceride and plasma metabolites in dairy cows. Journal of Dairy Science, Savoy, v.77, n.6, p.1521-1528, 1994.

WALKER W.L.; NEBEL R.L.; McGILLIARD M.L. Time of ovulation relative to mounting activity in dairy cattle. Journal of Dairy Science, Savoy, v.79, n.9, p.1555-1561, 1996.

WEAVER, L.D. Reproductive management programs for large dairies. In: MORROW, D.A. (Ed). Current therapy in theriogenology. 2.ed. Philadelphia : Saunders, 1986.

WILLIANSOM, D.H.; MELANBY, J.; KREBS, H.A. Enzymic determination of $\mathrm{D}(-)$ B-hydroxybutyric acid and acetoacetic acid in blood. Biochemistry Journal, v.82, n.1, p.90-96, 1962. 